\title{
Improving the Running Conditions of Diesel Engine with Grape Seed Oil Additives by Response Surface Design
}

\author{
Samet Uslu ${ }^{1 *}$, Murat Kadir Yeşilyurt ${ }^{2}$ \\ 0000-0001-9118-5108, $0000-0003-0870-7564^{2}$ \\ ${ }^{1}$ Mechanical Engineering Department, Faculty of Engineering, Karabuk University, Karabuk, Turkey \\ ${ }^{2}$ Mechanical Engineering Department, Faculty of Engineering and Architecture, Yozgat Bozok University, Yozgat, Turkey
}

\begin{abstract}
In this study, an optimization study was carried out by using Response Surface Methodology (RSM) to determine the optimum conditions by improving the working conditions in a single cylinder diesel engine using fuel blends created by mixing the biodiesel obtained from grape seed oil (GSO) to diesel in different proportions $(5 \%, 10 \%$ and $15 \%$ by vol.). Experiments were carried out with three different fuel mixtures with three different injection pressures (200, 225 and 250 bar) at three different engine loads $(400,1000$ and 1600 -Watt). Since the minimum number of experiments proposed by the RSM application is 20 for optimization according to three different factors and three different levels of each factor, an RSM model was created from the experiment data obtained by performing 20 trials. While the GSO ratio, the injection pressure and engine load was determined as input factors, brake specific fuel consumption (BSFC), exhaust gas temperature (EGT), carbon monoxide $(\mathrm{CO})$, hydrocarbon $(\mathrm{HC})$, nitrogen oxides $\left(\mathrm{NO}_{\mathrm{x}}\right)$ and smoke were chosen as responses on the RSM model. Considering the findings taken from the RSM model, the working conditions in which the best output can be obtained from the engine; it has been determined as 13\% GSO percentage, 245 bar injection pressure and $850-\mathrm{W}$ engine load. The study to verify the results obtained from the optimization study reveals that the results were obtained with an error of less than $9 \%$.
\end{abstract}

Keywords: Response surface, Optimization approach, Grape seed oil, Diesel engine

\author{
* Corresponding author \\ Samet Uslu \\ sametuslu@karabuk.edu.tr \\ Adress: Mechanical Engineering \\ Department, Faculty of Engineering, \\ Karabuk University, Karabuk, \\ Turkey
}

Research Article
Manuscript
Received $\quad 15.07 .2020$
Revised $\quad 05.09 .2020$
Accepted $\quad 07.09 .2020$
Doi: 10.30939/ijastech..770058

\section{Introduction}

Diesel engines are widely used in large sectors of the global economy, such as industry, transportation, and agriculture, due to their high efficiency [1-3]. Despite the high efficiency of diesel engines, their emissions, especially $\mathrm{NO}_{\mathrm{x}}$ and smoke emissions, have many negative effects on human health and the environment $[4,5]$. On the other hand, petroleum-based fuel reserves are running out rapidly due to the increase in world population and increasing energy demand in parallel with the development of the industry [6-9]. Studies on diesel engines are carried out for simultaneous reduction of fuel consumption and emissions due to both the depletion of fossil fuel reserves and high emission levels [10]. In this context, environmentally friendly renewable fuel research has accelerated in recent years and biofuels have emerged as an important alternative to fossil fuels [11-13].
Biodiesel is one step ahead in biofuels due to its advantage of being produced from many different substances [14-16]. There are various biodiesel raw materials such as fish oil, frying oil, and also oils of animal origin, as well as various vegetable origin substances, from soybeans to sunflower, canola to cotton seed oil [17-19]. In this study, GSO, which is in the category of biodiesel species of vegetable origin, was used. There are a limited number of studies in the literature about the use of GSO as fuel in diesel engines, and these studies are mostly done in marine engines or related to the production of GSO [20-22]. Azad and Rasul [23] examined the effects of using GSO and waste cooking oil as fuel in a fourcylinder, four-stroke diesel engine and compared two biodiesel results. According to their results, they stated that GSO gives better results in terms of both emission and performance. Vedagiri et al. [24] investigated the performance, 
combustion and emission parameters of a diesel engine powered by GSO biodiesel. In addition to GSO, they added nanocerium oxide and zinc oxide solids. They stated that by adding cerium oxide and zinc oxide emulsion mixtures, they achieved a significant decrease in $\mathrm{NO}_{\mathrm{x}}$ emission and that GSO is an effective alternative fuel for diesel engines without any engine changes.

The search for alternative fuel brought an increase in the number of experiments accompanied. Experiment is needed to measure the suitability of a new type of fuel for use in internal combustion engines. For this reason, both the number of experiments, the time spent, and the costs of the experiment have increased considerably in recent years $[25,26]$. To prevent this, in other words, to reduce the number of experiments, computer applications have been developed that can simulate many more experiments using a certain number of experiment data. Among these applications, RSM stands out due to its ability to optimize in a shorter time as it creates the most suitable matrix for tests, unlike other applications $[6,27]$. There are many studies in recent years where diesel engines have been optimized with RSM using different alternative fuels [28-31].

Although there are a few studies evaluating the usability of GSO as a fuel in a diesel engine, an optimization study about diesel engine using GSO as a fuel has not been found in the literature. For this reason, in this study, an optimization study of a diesel engine was made using RSM, where GSO ratio, injection pressure and load were selected as the input variable.

\section{Material and method}

In this study, which is done to improve the engine conditions and determine the best conditions, the experimental data required for the creation of the RSM model was obtained using the experimental setup shown schematically in Fig. 1. In the tests, the exhaust gas temperature values were measured with the type $\mathrm{J}$ (Fe-Const), TMX-B12F08 brand thermocouple, which can measure between $-200{ }^{\circ} \mathrm{C}$ and $800{ }^{\circ} \mathrm{C}$. Fuel consumption was mass-measured with the Weightlab brand WH-2002 model, which can measure 0.01 $\mathrm{g}$ precision. The resistive load set with control panel used in the loading of the test engine and seen in Figure 1 is composed of General brand $200 \mathrm{~W}$ and $1000 \mathrm{~W}$ halogen bulbs and switches. The Bilsa brand MOD 2210 model exhaust gas emission device used for the measurement of exhaust emissions can perform $\mathrm{CO}, \mathrm{HC}, \mathrm{NO}_{\mathrm{x}}$, air fuel ratio, lambda and smoke darkness measurements according to the principles specified in the TS 11365 / T1 standard. Technical characteristics of the engine/generator and exhaust emission device used in the experiments are shown in Table 1 and Table 2, respectively.

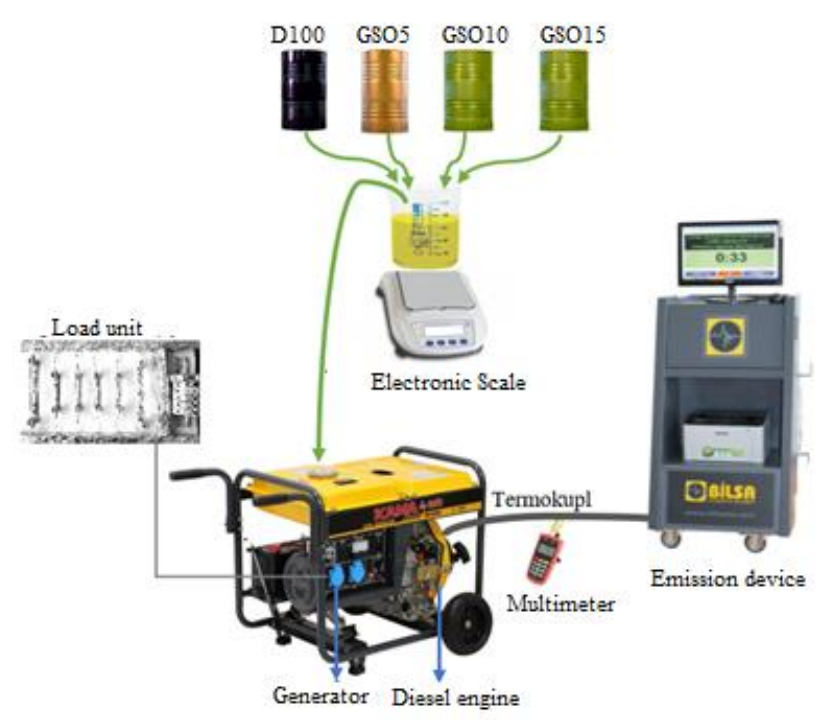

Fig. 1. Schematic view of experimental setup

Table 1. Factors and their levels.

\begin{tabular}{|c|c|}
\hline \multicolumn{2}{|c|}{ Diesel engine } \\
\hline Brand & Katana \\
\hline Model & $\mathrm{Km} 178 \mathrm{~F}$ \\
\hline Number of cycles & 4 \\
\hline Number of cylinders & 1 \\
\hline Stroke & $62 \mathrm{~mm}$ \\
\hline Bore & $78 \mathrm{~mm}$ \\
\hline Cylinder volume & $296 \mathrm{~cm}^{3}$ \\
\hline Maximum output power & $6.7 \mathrm{hp}$ \\
\hline Continuous output power & $6 \mathrm{hp}$ \\
\hline Compression ratio & $18: 1$ \\
\hline Engine speed & $3000 \mathrm{~d} / \mathrm{d}$ \\
\hline Fuel injection system & Direct injection \\
\hline Injection timing & $20^{\circ}$ KMA \\
\hline Injector nozzle number & 4 \\
\hline Intake system & Naturally aspirated \\
\hline Injection pressure & 200 bar \\
\hline Cooling system & Air-cooled \\
\hline \multicolumn{2}{|c|}{ Generator } \\
\hline Brand & Kama \\
\hline Model & KDL3500CE \\
\hline Power & $2.7 \mathrm{~kW}$ \\
\hline Maximum power & $3 \mathrm{~kW}$ \\
\hline Frequency & $50 \mathrm{~Hz}$ \\
\hline Current & $11.6 \mathrm{~A}$ \\
\hline Phase & 1 \\
\hline Voltage & $230 \mathrm{~V}$ \\
\hline
\end{tabular}




\begin{tabular}{|c|c|c|c|}
\hline Parameter & Unit & Range & Accuracy \\
\hline $\mathrm{CO}$ & $\%$ & $0-10$ & 0.001 \\
\hline $\mathrm{CO}_{2}$ & $\%$ & $0-19.99$ & 0.001 \\
\hline $\mathrm{HC}$ & $\mathrm{ppm}$ & $0-10000$ & 1 \\
\hline $\mathrm{O}_{2}$ & $\%$ & $0-25$ & 0.01 \\
\hline $\mathrm{NOx}$ & ppm & $0-5000$ & 1 \\
\hline Lambda & - & $0-5000$ & 0.001 \\
\hline Air/fuel ratio & - & $5-30$ & - \\
\hline Smoke opacity & $\%$ & $0-100$ & 0.1 \\
\hline Operating temperature & ${ }^{\circ} \mathrm{C}$ & $0-40$ & $\% 0.01$ \\
\hline Sensing time & $\mathrm{s}$ & $<5$ & - \\
\hline Feed voltage & $\mathrm{V} \mathrm{AC}$ & 220 & - \\
\hline Feed frequency & $\mathrm{Hz}$ & 50 & - \\
\hline
\end{tabular}

$$
y=\beta_{0}+\sum_{i}^{k} \beta_{i} x_{i}+\text { 무 }
$$

If the model is second-order;

$$
y=\beta_{0}+\sum_{i}^{k} \beta_{i} x_{i}+\sum_{i=1}^{k} \sum_{j \geq i}^{k} \beta_{i j} x_{i} x_{j}+\text { ? }
$$

Where $\mathcal{E}$ is random test error, $\mathrm{k}$ is the number of factors, $\mathrm{y}$ is the predicted response, $x_{i}$ and $x_{j}$ are independent factors [32] (Simsek and Uslu, 2020). $\beta_{0}$ is the constant, $\beta_{\mathrm{i}}$ is the linear coefficient and $\beta_{\mathrm{ij}}$ interactive coefficient, $i$ and $j$ are the linear and quadratic coefficient, respectively.

the experiments, GSO5 (5\% GSO + 95\% diesel) GSO10 (10\% GSO + 90\% diesel) and GSO15 (15\% GSO + $85 \%$ diesel) were used as fuel, which were obtained by adding GSO to the diesel in three different proportions. These three test fuels were tested at different injection pressure values (200, 225 and 250 bar) and at different engine loads (400, 1000 and 1600-W). Properties of test fuels are shown in Table 3.

Table 3. Properties of test fuels

\begin{tabular}{c|c|c} 
Properties & Diesel & Grapeseed oil \\
\hline Density at $15^{\circ} \mathrm{C}\left(\mathrm{kg} / \mathrm{m}^{3}\right)$ & 835 & $910-922.17$ \\
\hline $\begin{array}{c}\text { Kinematic viscosity at } 40^{\circ} \mathrm{C} \\
\left(\mathrm{mm}^{2} / \mathrm{s}\right)\end{array}$ & 2.85 & $26.42-37.32$ \\
\hline Cetane index $(-)$ & 46 & 48 \\
\hline Lower heating value $(\mathrm{MJ} / \mathrm{kg})$ & 42.6 & 36.54 \\
\hline Flash point $\left({ }^{\circ} \mathrm{C}\right)$ & 53 & 250.7 \\
\hline Water content $(\mathrm{ppm})$ & $<10$ & $390.8-1168$ \\
\hline Acid value $(\mathrm{mg} \mathrm{KOH} / \mathrm{g})$ & - & 2.1 \\
\hline Iodine value $(\mathrm{g} \mathrm{I} / 100 \mathrm{~g})$ & - & $72-136$ \\
\hline Free fatty acid content $(\%)$ & - & 0.6 \\
\hline Cloud point $\left({ }^{\circ} \mathrm{C}\right)$ & -10 & -7 \\
\hline Pour point $\left({ }^{\circ} \mathrm{C}\right)$ & -34 & -4
\end{tabular}

RSM model was created with the data obtained from the experimental study. RSM is one of the primary optimization applications that can be used to minimize money and time spent in academic and commercial tests. It can both derive a basic equation for the parameters to be optimized using a minimum number of experimental data and present it with $3 \mathrm{D}$ graphics. In addition, it is an application that can determine the effect of working parameters on outputs with the analysis of variance (ANOVA) and Pareto charts. RSM optimization is based on the equations given below;

The basic model based on a first-degree polynomial available in RSM;

The correlation coefficient $\left(\mathrm{R}^{2}\right)$ is assigned as per Eq. (3), the adjusted correlation coefficient (Adj. $R^{2}$ ) is assigned using Eq. (4), the predicted correlation coefficient (Pred. $\mathrm{R}^{2}$ ) is assigned using Eqs. (5) with Eqs. (6) and (7) [6] (Uslu, 2020);

$$
\begin{gathered}
R^{2}=1-\left[\frac{S S_{\text {residual }}}{S S_{\text {residual }}+S S_{\text {model }}}\right] \\
\text { Adj. } R^{2}=1-\left[\left(\frac{S S_{\text {residual }}}{d f_{\text {residual }}}\right) /\left(\frac{S S_{\text {residual }}+S S_{\text {model }}}{d f_{\text {residual }}+d f_{\text {model }}}\right)\right] \\
\text { Pred. } R^{2}=1-\left[\frac{P R E S S}{S S_{\text {residual }}+S S_{\text {model }}}\right] \\
\text { PRESS }=\sum_{i=1}^{n}(e-1)^{2} \\
e-1=\frac{e_{i}}{1-h_{i i}}
\end{gathered}
$$

In this optimization study, the input factors to be optimized are selected as the GSO ratio, the injection pressure and the engine load, while the outputs to achieve the best values are selected as BSFC, EGT, CO, HC, $\mathrm{NO}_{\mathrm{x}}$ and smoke. Factors selected for input are shown in Table 4, along with their levels.

Table 4. Input variables with levels.

\begin{tabular}{c|c|c|c} 
Variables & \multicolumn{3}{|c}{ Levels } \\
\hline GSO ratio (\% vol.) & 5 & 10 & 15 \\
\hline Injection pressure (bar) & 200 & 225 & 250 \\
\hline Engine load (watt) & 400 & 1000 & 1600
\end{tabular}

\section{Results and Discussion}

The $\mathrm{R}^{2}$ is an evidence of how the test data fit with the models. The $\mathrm{R}^{2}$ of BSFC, EGT, $\mathrm{HC}, \mathrm{CO}, \mathrm{NO}_{\mathrm{x}}$, and smoke are $99.67 \%, 90.17 \%, 94.93 \%, 94.88 \%, 91.22 \%$ and $90.07 \%$, respectively which are supplying high-level accurate results of 
the model compared the experimental outcomes. Each response has $\mathrm{R}^{2}$ bigger than $90 \%$.

Second order equations duplicate by regards to the operating variables to estimate the responses of BSFC, EGT, HC, $\mathrm{CO}, \mathrm{NO}_{\mathrm{x}}$ and smoke are performed by equations (8), (9), (10), (11), (12) and (13), respectively.

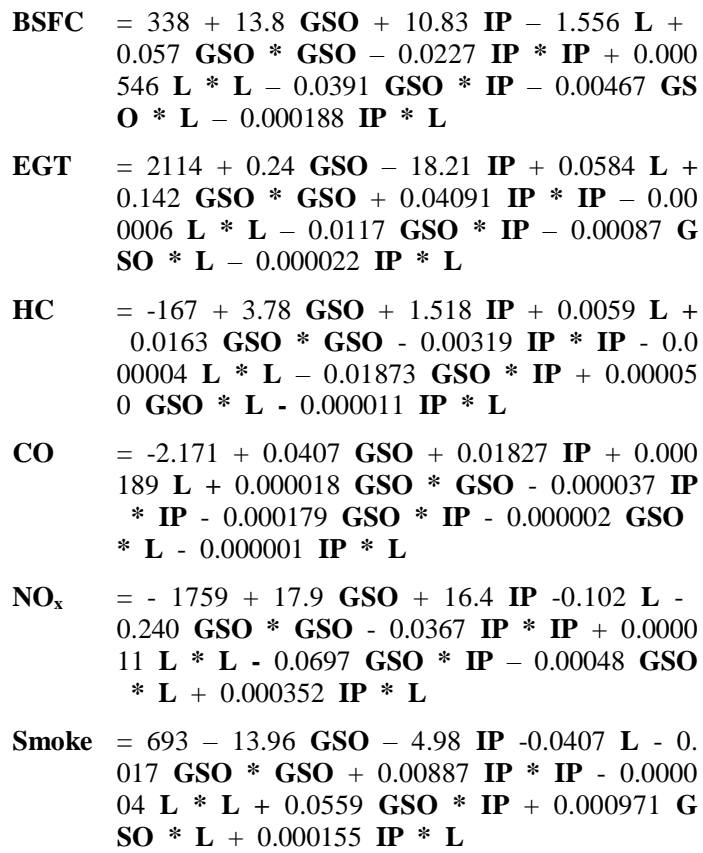

Where GSO, IP and L characterize GSO percentage, injection pressure and engine load, respectively.

Fig. 2 shows the effects of the selected variables on BSFC and EGT simultaneously. It is desirable that BSFC and EGT are at low levels. Looking at 3D graphics, the increase in GSO rate caused BSFC to increase. Considering

Table 3, where the fuel properties are shown, the lower heating value of the diesel is $42.6 \mathrm{MJ} / \mathrm{kg}$, while the GSO is $36.54 \mathrm{MJ} / \mathrm{kg}$. Therefore, as the amount of GSO increases in the fuel mixture, the lower thermal value of the mixture will decrease. In order to obtain the equal outlet power from the engine, it is essential to utilize more fuel with low thermal value. Therefore, BSFC increased with the use of GSO. On the other hand, if the BSFC change is examined according to the load variation, it is clearly understood from the graph that BSFC decreases as the load increases. It is a known fact that as the load increases, the temperature inside the cylinder increases. Along with the increased in-cylinder temperature, the combustion temperature also rises, and as a result, the exact combustion rate increases. This situation reduces BSFC. The injection pressure changes increased BSFC up to 225 bar and after 225 bar, BSFC tended to decrease again. Since the viscosity of GSO is very high, incomplete combustion occurred at low pressures and BSFC increased. BSFC is thought to decrease as the rate of incomplete combustion decreases with increasing pressure.
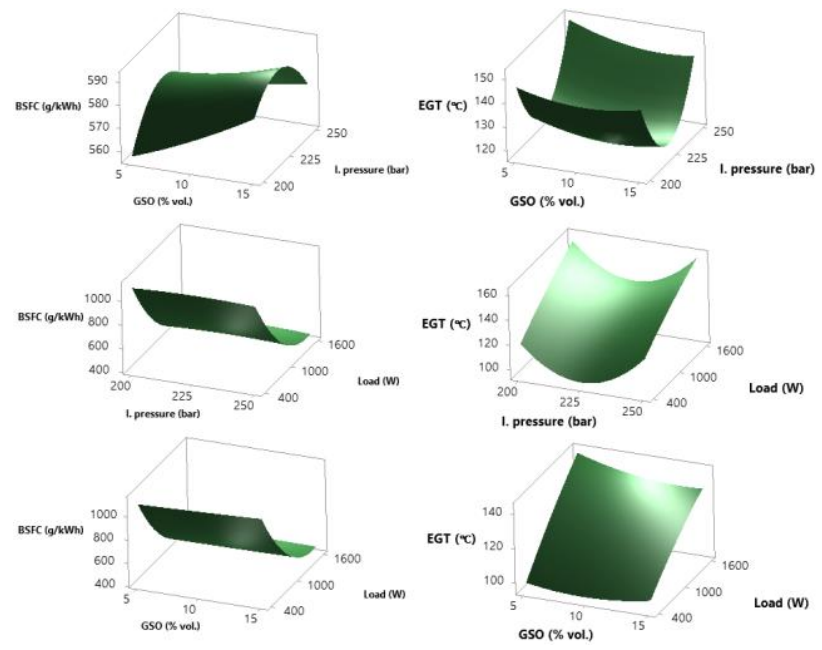

Fig. 2. Simultaneous effects of engine variables on BSFC and EGT

Simultaneous effects of engine variables on $\mathrm{CO}$ and $\mathrm{HC}$ emissions are demonstrated in Fig. 3. The main factor triggering both $\mathrm{CO}$ emission and $\mathrm{HC}$ emission formation is incomplete combustion. All factors that increase incomplete combustion also cause $\mathrm{CO}$ and $\mathrm{HC}$ to increase. It was mentioned in the explanation of an upper graph that the rate of complete burning increases with increasing engine load. Consequently, as the engine load increases, $\mathrm{CO}$ and $\mathrm{HC}$ emissions must decrease, and the graph has given supporting results. On the other hand, $\mathrm{CO}$ and $\mathrm{HC}$ emissions have increased as the incomplete combustion has increased with the increase of GSO, whose kinematic viscosity is quite high compared to diesel. Since the spraying difficulty caused by the effect of high viscosity is relatively resolved at high injection pressure values, $\mathrm{CO}$ and $\mathrm{HC}$ emissions decrease as the pressure increases.

Changes in smoke and $\mathrm{NO}_{\mathrm{x}}$ depending on engine variables are shown in Fig. 4. $\mathrm{NO}_{\mathrm{x}}$ is a type of emission that occurs mostly due to high temperatures and oxygen excess. Consequently, it increased with the increasing load of the engine, which increased the temperature inside the cylinder, and decreased with increasing GSO due to the cooling effect of GSO. Similarly, smoke emission increased with increasing engine load and decreasing with increasing GSO rate. The injection pressure value with the highest smoke and $\mathrm{NO}_{\mathrm{x}}$ emission was determined as 225 bar. Emissions decreased as the rate of complete combustion reaction increased at higher pressures. 


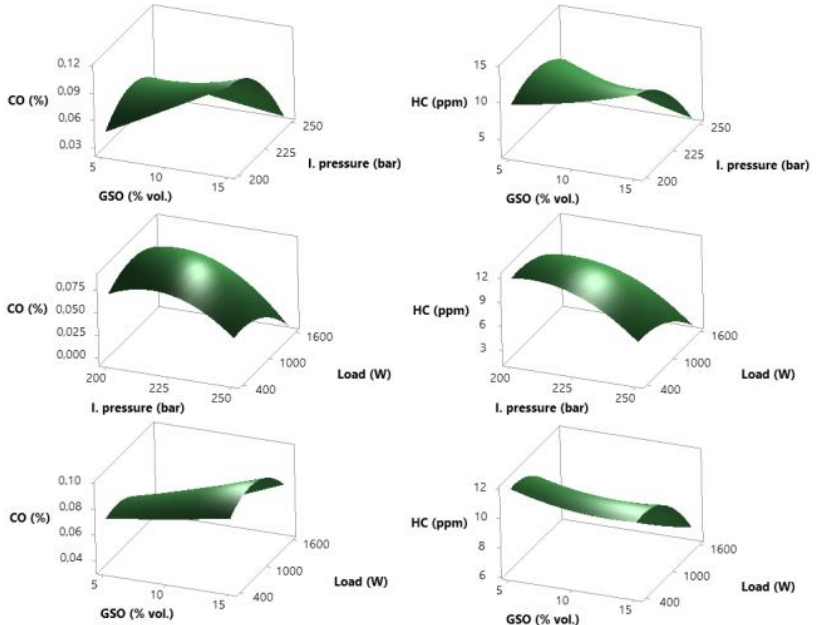

Fig. 3. Simultaneous effects of engine variables on $\mathrm{CO}$ and $\mathrm{HC}$

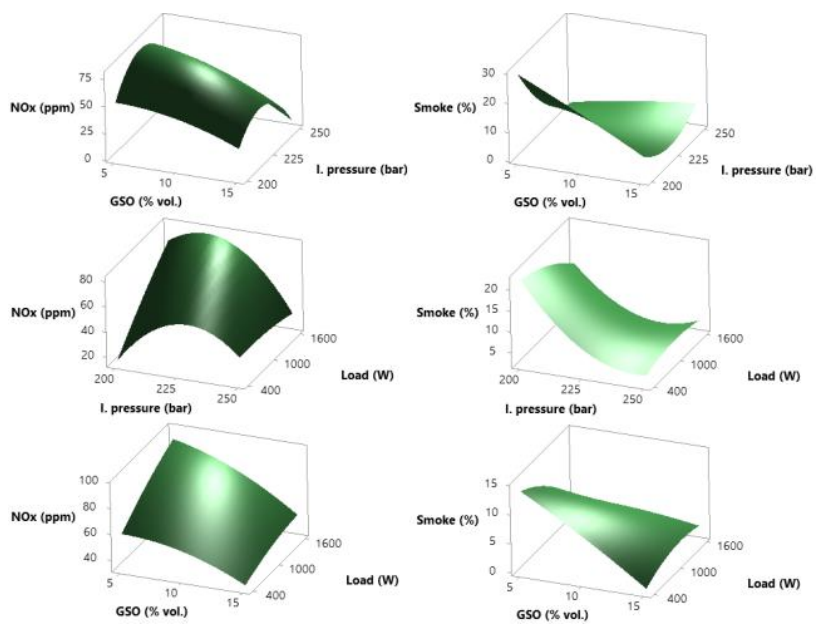

Fig. 4. Simultaneous effects of engine variables on Smoke and $\mathrm{NO}_{\mathrm{x}}$ emissions

\subsection{Optimization and Validation}

The main purpose of this study is to optimize the selected input variables and the responses arising from these variables. Accordingly, the criteria of the optimization study are shown in Table 5. All the responses that are required to be minimum in internal combustion engine processes. Therefore, it was chosen to minimize all responses as optimization criteria.

Results obtained from the optimization study based on the selected criteria are shown in Fig. 5. Considering the findings taken from the RSM model, the working conditions in which the best responses can be obtained from the engine; it has been determined as $13 \%$ GSO percentage, 245 bar injection pressure and $850-\mathrm{W}$ load. According to the optimum working conditions obtained, the responses are $675.82 \mathrm{~g} / \mathrm{kWh}$, $130.32{ }^{\circ} \mathrm{C}, 25.732 \mathrm{ppm}, 5.245 \%, 3.542 \mathrm{ppm}$ and $0.023 \%$ for BSFC, EGT, $\mathrm{NO}_{x}$, smoke, $\mathrm{HC}$, and $\mathrm{CO}$, respectively.
Table 5. Optimization principles

\begin{tabular}{c|l|c|c|c} 
Name & Goal & Lower & Upper & Importance \\
\hline GSO ratio & In range & 5 & 15 & 1 \\
\hline $\begin{array}{c}\text { Injection } \\
\text { pressure }\end{array}$ & In range & 200 & 250 & 1 \\
\hline Load & In range & 400 & 1600 & 1 \\
\hline $\begin{array}{c}\text { BSFC } \\
(\mathrm{g} / \mathrm{kWh})\end{array}$ & Minimize & & & 1 \\
\hline EGT $\left({ }^{\circ} \mathrm{C}\right)$ & Minimize & & & 1 \\
\hline $\mathrm{CO}(\%)$ & Minimize & & & 1 \\
\hline $\mathrm{HC}(\mathrm{ppm})$ & Minimize & & & 1 \\
\hline $\mathrm{NO}_{\mathrm{x}}(\mathrm{ppm})$ & Minimize & & & 1 \\
\hline Smoke $(\%)$ & Minimize & & & 1
\end{tabular}

$\begin{array}{ccccc}\text { New } & & \text { GSO }(\% \mathrm{~V} & \text { I. press } & \text { Load }(W) \\ \text { D: } 0,7515 & \text { High } & 15,0 & 250,0 & 1600,0 \\ & \text { Cur } & {[13,0]} & {[245,0]} & {[850,0]} \\ & \text { Low } & 5,0 & 200,0 & 400,0\end{array}$

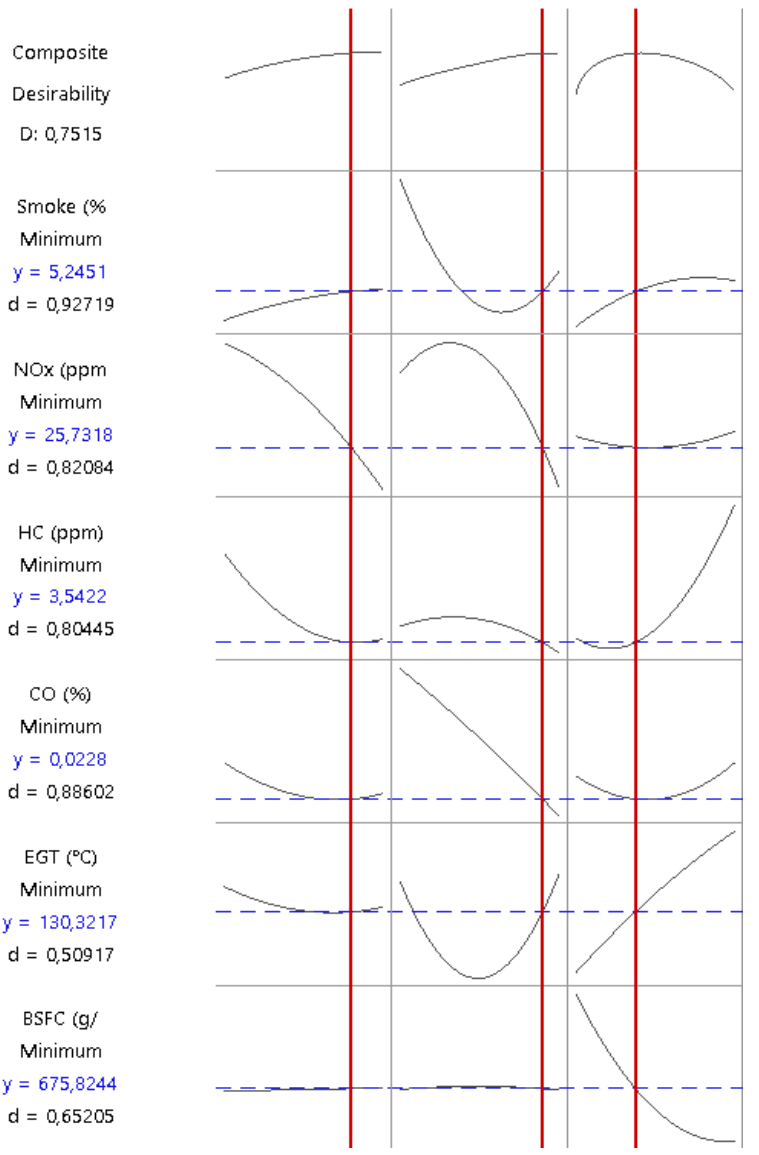

Fig. 5. Optimized results

It is extremely important to determine how closely the optimized results and the experimental results converge. Because one of the leading goals in the optimization study is to reduce the number of tests. While reducing the number of tests, it is an important criterion not to get away from the experimental results. 
A verification study was carried out to compare the optimization results and the test results. For the verification study, an experimental study was performed with the optimum working conditions obtained from RSM optimizer. The results were compared as shown in Table 6. The scale in comparison is the magnitude of the error rate. Looking at the error rates, they are all lower than $9 \%$. The lowest error rate was obtained in EGT with 3.44\%, while the highest error occurred in $\mathrm{HC}$ with $8.71 \%$. When the literature information is examined, it is understood that error rates less than $9 \%$ are at acceptable levels.

Table 6. Verification evaluations for optimized and experimental results with \% error.

\begin{tabular}{c|c|c|c}
$\begin{array}{c}\text { GSO } \\
\text { Ratio }(\boldsymbol{\%})\end{array}$ & $\begin{array}{c}\text { I. Pressure } \\
\text { (bar) }\end{array}$ & $\begin{array}{c}\text { Load } \\
\text { (watt) }\end{array}$ & \\
\hline 13 & 245 & 850 & \\
\hline BSFC (g/kWh) & 675.82 & 705.4 & 4.37 \\
\hline EGT ( $\mathbf{\circ} \mathbf{C})$ & 130.32 & 134.8 & 3.44 \\
\hline CO (\%) & 0.023 & 0.037 & 7.83 \\
\hline HC (ppm) & 3.542 & 4.94 & 8.71 \\
\hline NOx $(\mathbf{p p m})$ & 25.732 & 22.51 & 8.63 \\
\hline Smoke (\%) & 5.245 & 4.365 & 7.25
\end{tabular}

\section{Conclusions}

In this study, RSM model has been developed for the improvement of a GSO doped diesel engine operating at different injection pressures and different loads. The following conclusions have been obtained;

$\checkmark$ Optimum engine variables were determined as $13 \%$ GSO percentage, 245 bar injection pressure and 850W load with RSM optimization.

$\checkmark$ Responses obtained based on optimum working conditions for BSFC, EGT, $\mathrm{NO}_{\mathrm{x}}$, smoke, $\mathrm{HC}$, and $\mathrm{CO}$ are $675.82 \mathrm{~g} / \mathrm{kWh}, 130.32{ }^{\circ} \mathrm{C}, 25.732 \mathrm{ppm}, 5.245 \%$, $3.542 \mathrm{ppm}$ and $0.023 \%$, respectively.

$\checkmark \quad$ The error rates between the optimum responses and experimental responses are less than $9 \%$. The lowest error rate was obtained in EGT with $3.44 \%$, while the highest error occurred in $\mathrm{HC}$ with $8.71 \%$.

$\checkmark \quad$ The magnitude of $\mathrm{R}^{2}$ values, which is an indicator of the significance of the results in statistical studies, was found as $99.67 \%, 90.17 \%, 94.93 \%, 94.88 \%$, $91.22 \%$ and $90.07 \%$ for BSFC, EGT, HC, CO, $\mathrm{NO}_{\mathrm{x}}$, and smoke, respectively. Each response has $\mathrm{R}^{2}$ values bigger than $90 \%$.
According to the results of the study, it is understood that a diesel engine with a GSO contribution will be successfully optimized with RSM according to the level change of different variables.

\section{Nomenclature}

$\begin{array}{ll}\text { ANOVA } & \text { Analysis of variance } \\ \beta_{\mathrm{i}} & \text { linear coefficient } \\ \beta_{\mathrm{ij}} & \text { interactive coefficient } \\ \beta_{0} & \text { constant } \\ \text { BSFC } & \text { Brake specific fuel consumption } \\ \mathrm{CO} & \text { Carbon monoxide } \\ \mathcal{E} & \text { random test error } \\ \text { EGT } & \text { Exhaust gas temperature } \\ \text { GSO } & \text { Grape seed oil } \\ \text { GSO5 } & 5 \% \text { grape seed oil }+95 \% \text { diesel } \\ \text { GSO10 } & \text { 10\% grape seed oil }+90 \% \text { diesel } \\ \text { GSO15 } & \text { 15\% grape seed oil }+85 \% \text { diesel } \\ \text { HC } & \text { Hydrocarbon } \\ i & \text { Linear coefficient } \\ j & \text { Quadratic coefficient } \\ \text { k } & \text { Number of factors } \\ \text { NOx } & \text { Nitrogen oxides } \\ \text { R }^{2} & \text { Correlation coefficient } \\ \text { Adj. R } & \text { Adjusted correlation coefficient } \\ \text { Pred. R } & \text { Predicted correlation coefficient } \\ \text { RSM } & \text { Response surface methodology } \\ x_{i}, x_{j} & \text { Independent factors } \\ \mathrm{y} & \text { Predicted response } \\ & \end{array}$

\section{References}

[1] Santhosh, K., Kumar, G.N., Radheshyam, Sanjay, P.V., (2020). Experimental analysis of performance and emission characteristics of CRDI diesel engine fueled with 1-pentanol/diesel blends with EGR technique, Fuel, 267.

[2] Yesilyurt, M. K., (2020). The examination of a compressionignition engine powered by peanut oil biodiesel and diesel fuel in terms of energetic and exergetic performance parameters, Fuel, 278, 118319.

[3] Yesilyurt, M.K., Aydin M., Yilbasi, Z., Arslan, M., (2020). Investigation on the structural effects of the addition of alcohols having various chain lengths into the vegetable oil-biodieseldiesel fuel blends: An attempt for improving the performance, combustion, and exhaust emission characteristics of a compression ignition engine, Fuel, 269, 117455.

[4] Vigneswaran, R., Annamalai, K., Dhinesh, B., Krishnamoorthy, R., (2018). Experimental investigation of unmodified diesel engine performance, combustion and emission with multipurpose additive along with water-in-diesel emulsion fuel, Energy Conversion and Management, 172, 370-380.

[5] Pan, H., Li, H., Zhang, H., Wang, A., Jin, D., Yang, S., (2018). 
Effective production of biodiesel from non-edible oil using facile synthesis of imidazolium salts-based Brønsted-Lewis solid acid and co-solvent, Energy Conversion And Management, 166, 534-544.

[6] Uslu, S., (2020). Optimization of diesel engine operating parameters fueled with palm oil-diesel blend: Comparative evaluation between response surface methodology (RSM) and artificial neural network (ANN), Fuel, 276117990.

[7] Yesilyurt, M. K., (2020). A detailed investigation on the performance, combustion, and exhaust emission characteristics of a diesel engine running on the blend of diesel fuel, biodiesel and 1-heptanol (C7 alcohol) as a next-generation higher alcohol, Fuel, 275, 117893.

[8] Doğan, B., Erol, D., Yaman, H., Kodanli, E., (2017). The effect of ethanol-gasoline blends on performance and exhaust emissions of a spark ignition engine through exergy analysis, Applied Thermal Engineering, 120, 433-443.

[9] Doğan, B. and Erol, D., (2019). The future of fossil and alternative fuels used in automotive industry, 3rd International Symposium on Multidisciplinary Studies And Innovative Technologies (ISMSIT), 1-8.

[10]Rajak, U., Nashine, P., Verma, T.N., (2020). Effect of spirulina microalgae biodiesel enriched with diesel fuel on performance and emission characteristics of CI engine, Fuel, 268.

[11]Nanthagopal, K., Ashok, B., Garnepudi, R.S., Tarun, K.R., Dhinesh, B., (2019). Investigation on diethyl ether as an additive with Calophyllum Inophyllum biodiesel for CI engine application, Energy Conversion and Management, 179, 104-113.

[12]Uslu, S. and Celik, M. B., (2018). Prediction of engine emissions and performance with artificial neural networks in a single cylinder diesel engine using diethyl ether, Engineering Science and Technology, an International Journal, 21, 6.

[13]Fayyazbakhsh, A. and Pirouzfar, V., (2017). Comprehensive overview on diesel additives to reduce emissions, enhance fuel properties and improve engine performance, Renewable And Sustainable Energy Reviews, 74, 891-901.

[14]Datta, A. and Mandal, B. K., (2016). A comprehensive review of biodiesel as an alternative fuel for compression ignition engine, Renewable and Sustainable Energy Reviews, 57, 799821.

[15]Venu, H., Subramani, L. and Raju, V. D., (2019). Emission reduction in a DI diesel engine using exhaust gas recirculation (EGR) of palm biodiesel blended with $\mathrm{TiO}_{2}$ nano additives, Renewable Energy, 140, 245-263.

[16]Yesilyurt, M.K. and Aydin M., (2020). Experimental investigation on the performance, combustion and exhaust emission characteristics of a compression-ignition engine fueled with cottonseed oil biodiesel/diethyl ether/diesel fuel blends, Energy Conversion and Management, 205, 112355.

[17]Chandran, D., (2020). Compatibility of diesel engine materials with biodiesel fuel, Renewable Energy, 147, 89-99.

[18]Hajlari, S. A., Najafi, B., Ardabili, S. F., (2019). Castor oil, a source for biodiesel production and its impact on the diesel engine performance, Renewable Energy Focus, 28, 1-10.
[19]Krishnamurthy, K. N., Sridhara, S. N. and Ananda Kumar, C. S., (2020). Optimization and kinetic study of biodiesel production from Hydnocarpus wightiana oil and dairy waste scum using snail shell $\mathrm{CaO}$ nano catalyst, Renewable Energy Energy, 146, 280-296.

[20]Karthikeyan, S., Prathima, A., Elango, A., Silaimani, SM., (2015). Environmental Effect of vitis vinifera (Grape Seed oil) biofuel blends in Marine Engine, Indian Journal of Geo-Marine Sciences, 44 (12), 1852-1856.

[21]Fernandez, C. M., Ramos, M. J., Perez, A., Rodriguez, J. F., (2010). Production of biodiesel from winery waste: Extraction, refining and transesterification of grape seed oil, Bioresource Technology, 101 (18), 7019-7024.

[22]Singh, G., Mohapatra, S. K., Ragit, S. S., Kundu, K., (2018). Optimization of biodiesel production from grape seed oil using Taguchi's orthogonal array, Energy Sources, Part A: Recovery, Utilization, And Environmental Effects, 40 (18), 2144-2153.

[23]Azad, K. and Rasul, M., (2019). Performance and combustion analysis of diesel engine fueled with grape seed and waste cooking biodiesel, Energy Procedia, 160, 340-347.

[24]Vedagiri, P., Martin, L. J., Varuvel, E. G., Subramanian, T., (2019). Experimental study on $\mathrm{NO}_{\mathrm{x}}$ reduction in a grapeseed oil biodiesel-fueled CI engine using nanoemulsions and SCR retrofitment, Recent Advancements In Chemical, Environmental And Energy Engineering.

[25]Mehra, R. K., Duan, H., Luo, S., Rao, A., and Ma, F., (2018). Experimental and artificial neural network (ANN) study of hydrogen enriched compressed natural gas (HCNG) engine under various ignition timings and excess air ratios, Applied Energy, 228, 736-754.

[26]Aydın, M., Uslu, S., Çelik, M. B., (2020). Performance and emission prediction of a compression ignition engine fueled with biodiesel-diesel blends: A combined application of ANN and RSM based optimization, Fuel, 269.

[27]Yusri, I. M., Abdul Majeed, A. P. P., Mamat, R., Ghazali, M. F., Awad, O. I., and Azmi, W. H., (2018). A review on the application of response surface method and artificial neural network in engine performance and exhaust emissions characteristics in alternative fuel, Renewable And Sustainable Energy Reviews, 90, 665-686.

[28]Subramani, S., Govindasamy, R., Rao, G. L. N., (2020). Predictive correlations for $\mathrm{NO}_{x}$ and smoke emission of DI CI engine fuelled with diesel-biodiesel-higher alcohol blends-response surface methodology approach, Fuel, 269, 117304.

[29]Parida, M.K., Joardar, H., Rout, A.K., Rputaray, I., Mishra, B.P., (2019). Multiple response optimizations to improve performance and reduce emissions of Argemone Mexicana biodiesel-diesel blends in a VCR engine, Applied Thermal Engineering, 148, 1454-1466.

[30]Singh, Y., Sharma, A., Singh, G. K., Singla, A., and Singh, N. K., (2018). Optimization of performance and emission parameters of direct injection diesel engine fuelled with pongamia methyl esters-response surface methodology approach, Industrial Crops \& Products, 126, 218-226. 
[31]Elkelawy, M., Bastawissi, H., Esmaeil, K. K., Radwan, A. M., Panchal, H., Sadasivuni, K. K., Suresh, M., Israr, M., (2020). Maximization of biodiesel production from sunflower and soybean oils and prediction of diesel engine performance and emission characteristics through response surface methodology, Fuel, 266, 117072.

[32]Simsek, S., Uslu, S. (2020). Investigation of the effects of biodiesel/2-ethylhexyl nitrate (EHN) fuel blends on diesel engine performance and emissions by response surface methodology (RSM), Fuel, 275, 118005. 